\title{
Programmatic Communication for Religious Peace in Nigeria: Lessons Learned from Indonesia
}

\author{
Nnamdi C Nwanyanwu*, Nwokezi J Ikoro and Samuel C Eke
}

Department of Mass Communication, School of Humanities and Social Science, Rivers State College of Arts and Science Rumuola, Port Harcourt, USA

\begin{abstract}
This article is a sustainable programmatic communication framework which links lessons from Indonesia in the era of the Laskar Jihadists (a militant Muslim faction) and "Boko Haram Sect "insurgence in Nigeria. The article verifies a previous peer group conference paper conceived at Ohio University in 2005. Original empirical data sets derived from authentic personal communication and professional instructions guided the translation of the lessons to realistic socio scientific knowledge. Social mobilization model was used to conceptualize this article. Security forces have not been able to control or prevent or adequately address religious conflict violence, peace and freedom in Indonesian and Nigerian. Programmatic communication campaign should be used to promote inter-religious peace and freedom in these countries' contemporary relationships between Muslims and Christians.
\end{abstract}

Keywords: Sustainable; Programmatic; Communication; Religion; Ideology; Peace; Freedom

\section{Introduction}

Ambon, the capital of the Maluku Province of Indonesia has been facing religious conflicts between Christians and Muslims for several hundred years. In 1999, there was a rise in incidents of inter-religious violence. The first major conflict in Maluku began on January19, 1999 when the Christian University in Ambon was attacked in 2000 [1]. The conflict spread out rapidly to other areas of the province and then to other islands of the country. The religious war was initiated in the Ambon City between Christian and Muslim political powers (economic and military). The second conflict occurred in June 2000 and was led by the Laskar Jihadists (a militant Muslim faction).

Army troupes and police personnel of Islamic extraction supported the Muslim fighters with equipment and standard military weapons. During the conflicts more than 5,000 people were killed and around 700,000 people became refugees. This translates to nearly one third of the population of Maluku Province in Indonesia.

Currently, there is a struggle for political power and economic dominance within the province. The vast majority of Christians and Muslims do not associate with one another and the groups remain divided in all social and cultural aspects. Separate schools, stores, restaurants, and neighborhoods exist for Christians and Muslims. Universities are also divided by religion (e.g. the Islamic University of Darussalam, State Pattimura University, and Christian University in Ambon). Children are not allowed to play with those of a different religion.

The roots of the Maluku conflict trace back to the beginning of the 350-year colonization of Indonesia by the Dutch. During the colonial period, missionaries exposed, promoted and converted the people to Christianity. The Christian dominance lasted until the Indonesian Republic declared its independence in 1945. In the two and half decades of post independence, majority of Maluku's population, including Ambon city, became predominantly Christian, while the majority of Indonesians were Muslims.

Many Muslims migrated to Ambon city from the other parts of Indonesia following the adaptation of a New Order, Indonesia's national model, by President Suharto from 1967 to 1998. After the fall of President Suharto in 1999, political power shifted to Ambon city. In 2000 a national and provincial elections were conducted. The political movement began to build up in Ambon city as religious ideology. In 2001, the population of the province broke down into two divides: Muslims and Christians. Muslim leaders in Ambon city were convinced that Christians had initiated the conflict while Christians believed Muslims are responsible.

\section{Methodology}

The original ideas of this article were derived from a peer group conference paper conceived by Jennifer Cunningham (USA), Yumiko Harada (Japan), Nodira Karimzoda (Pakistan), Ami Sengupta (India) and Nwokezi John Ikoro (Nigeria) in the Fall Quarter of 2005 in Ohio University, Athens, United States of America. The peer group was formed during the International Graduate Education class in Communication and Development studies. The peer group members studied tracking intractable religious conflict in Indonesia.

In the second semester of 2012, Mr. Nwokezi J. Ikoro in collaboration with Sir Samuel C. Eke (Nigeria) and Nnamdi Nwanyanwu (Nigeria) reviewed and expanded the original idea by localizing the context to what should be done to reduce incidence of Christological disputes and internal political ideological hegemony (Jihads) in the Nigerian polity.

Key primary and credible secondary sources, comprising personal interviews, books, magazines, reports, internet documents, organized personal communication; academic advice, guidance and scholarly collaborations were used to writing this article.

\section{Objectives}

The measurable behavioral objective of this article is to reduce

*Corresponding author: Nnamdi C. Nwanyanwu, Department of Mass Communication, School of Humanities and Social Science, Rivers State College of Arts and Science Rumuola, Port Harcourt, USA, E-mail: nnams07@yahoo.com

Received January 30, 2013; Accepted March 15, 2013; Published March 22, 2013

Citation: Nwanyanwu NC, Ikoro NJ, Eke SC (2013) Programmatic Communication for Religious Peace in Nigeria: Lessons Learned from Indonesia. J Mass Communicat Journalism 3: 150. doi:10.4172/2165-7912.1000150

Copyright: (c) 2013 Nwanyanwu NC, et al. This is an open-access article distributed under the terms of the Creative Commons Attribution License, which permits unrestricted use, distribution, and reproduction in any medium, provided the original author and source are credited. 
the incidence of violent conflicts at $50 \%$ by the end of the campaign in 30 months. The specific objective of this article is to reduce the incidence of religious conflicts violence in Nigeria, in this era of "Boko Haram militant Sect", while the general objective is to achieve religious freedom, harmony and peace in Nigeria with the lessons learned from Indonesia.

The performance objectives is to promote peace, tolerance for religious freedom, harmony and unity among Muslims and Christians in Northern Nigeria with instilling of a sense of secular nationhood as experienced in Ambon Province of Indonesia at present.

The campaign planners should identify the targets and train them for critical strategic communication campaign with a view to reduce incidence of violence with initiated outreach sustainable programmatic communication for many inter-religious families, students as peace ambassadors and religious leaders within the first year.

The critical strategic communication campaign should aim at spreading awareness about building multi-pronged sustainable religious peace and harmonious virtues, to at least $75 \%$ Christians and Muslims populations in Nigeria.

\section{Conceptual framework}

There are barriers to the resolution of religious violent conflicts in Nigeria. Critical strategic communication campaign should be used to break these barriers. The critical strategic communication campaign is a planned social action for a period of 30 calendar months. The initial six months may be dedicated to the development and production of campaign materials with peace building outreach efforts.

The social mobilization conceptual model is recommended for this critical strategic communication because it has been prove in the utility of behaviour change. Social mobilization conceptual model is a suitable means to promote and establish a climate of acceptance and change in a culture of religious diversity. In the context of this article, social mobilization is defined as the process of bringing together all feasible and practical intersectoral partners and allies to determine felt-needs and raise awareness of demand for a nonviolence religious behaviour development in Nigerian polity.

According to McKee [2] social mobilization involves enlisting the participation key factors, institutions, groups and communities, in identifying, raising and managing human and material resources, thereby increasing and strengthening self-reliance and sustainability of achievements. The key idea behind social mobilization in critical strategic communication campaign is that of "partnership building" (pp. 108-109).

The authors of this article believe that a campaign involving deep personal religion ideology requires more than a mass media campaign and necessitates the involvement of social factors, families, opinion leaders and community members in the involvement and commitment of diverse partners such as religious leaders, local officials and students who can help accelerate the reach and the acceptance of the campaign ideas.

In recognize of the use of this participatory model of communication, it can be used by Muslim and Christian students to identify their own concerns regarding violence conflict to design component of their religious mores. It is only when people are involve in evolving behaviour change that they can set their own agenda and through participatory processes people can realistically cater for their socio scientific behavoural needs [2].
This is especially applicatory in Nigeria where social media, schools, markets, mercantile institutions, information and communication technologies tools, construction and agro-processing industries are basically open to all religious believers.

\section{Reflexive analysis}

Indonesia is a country which consists of approximately 17,000 islands and 200 ethnic groups-each having its own languages or dialects. This makes the issue of religious conflicts very difficult to address because Indonesia is multi-cultural and multi-lingual. People in Ambon City speak Bahasa, the official Indonesian language with Ambon being a regional language.

Indonesia, during the last periods of the Suharto's regime, from 1997 to 1999, was accompanied with a large number of religious conflicts with political power sharing distribution issues problems. On January 19, 1999 petty argument in the city of Ambon triggered the Christian-Muslim clashes that lasted for three years across Maluku. As many as 10,000 people were killed and 700,000 or one third of the region's population displaced.

In addition to religious conflicts, a highly centralized government was a significant barrier to conflict resolution in Indonesia [3]. Although at present local governments are more empowered than they were during the Suharto regime, some parts of Indonesia still lack the opportunity of decision-making such as distribution of the budgets and natural resources. It is on record that masses are often uncomfortable with centralized power systems, the authors of this article feel that the participatory nature of the campaign will be well accepted because it will enable people to make informed decisions that concern their lives.

In combating the problems, government and its security forces have not been able to control or prevent religious ideology tension in Maluku Province of Indonesia. The military officials do not possess the authority to be involved in religious conflict unless they were requested by the police; and the police officials do not have the authority to restrict people from traveling to other provinces of Indonesia.

Many international organizations such as United Nations Development Programme (UNDP), the World Bank (WB), the International Committee of the Red Cross (ICRC), local and International Nongovernmental Organization (NGOs) have been involved in the conflict resolution in Ambon City. The UNDP funds two major projects in Ambon City for Journalists and local NGOs advancing religious ideology reconciliation in rural areas of the province. International human rights agencies, Amnesty International and Pact Indonesia, are also working to resolve the intractable religious conflicts in Indonesia. There are two local NGOs working on conflict resolution in Ambon City, Peace-Building Institute; and Baku Bae (Reconciliation), Legal Aid Foundation and the Commission for Disappearance (i.e. ethnic cleansing via politico-religious militancy) and Victims of Violence Projects for conflict resolution in Ambon City.

In the context of Nigeria, this article seeks for commissioning of critical strategic communication campaign for religious ideology peace. Programmatically, if carried out, the campaign will reduce incidents of religious extremism and fundamentalists' violence and conflicts among Christians and Muslims with lessons learned from in Indonesia. The growing incidence of inter-religious violence conflicts with political coloration in Nigeria, since 1999 is clear and present danger. The critical strategic communication campaign is based on independent and professional insights of the authors of this article. The idea from the situation analysis requires a better understanding of both the causes 
and the manifestations of conflicts in Indonesia.

The ideas design of the campaign is based upon the ' $\mathrm{P}$ ' process for strategic communication [4]. Using this programmatic framework the authors of this article followed six time tests steps systematic design of communication campaign. Among the key strengths of the ' $\mathrm{P}$ ' process are that it allows the programmer to respond to inputs from the targeted groups. The steps are: analysis, strategic design, development, management, impacts evaluation and planning for continuity.

The target design should be as defined according to Singhal and Rogers [5] "targeting is the process of customizing the design and delivery of a communication programme, on the basis of the characteristics of an intended audience segment". This critical strategic communication campaign should primarily target Muslims and Christians, Islamic populations, "states, organizations" and institutions of finance and shari'a jihad Ehrenfeld, and Lappen, cited in Norwitz [6] in schools and universities. Students have historically played a critical role in social movements in Indonesia. Additionally students are the future generation and are most benefited by a peaceful nation where they grow and develop in all spheres of their lives.

The secondary targets should be neutral citizens who can help implement this critical strategic communication campaign through peace-promoting theaters, puppetry and radio and TV programmes. There are many families in Indonesia who have a mixture of Muslim and Christian ancestry that maintains open communication between the groups [3]. It is the hope of the authors of this article that MuslimChristian family units should help spread the message of unity in diversity to their friends and associates through social diffusion and mobilization.

Gaining the help of religious leaders would also be a great benefit to the critical strategic communication campaign. Firstly, the religious nature of the conflict requires that citizens of Indonesia in the province under study should be involved and be committed to religious leaders who can promote the idea of religious tolerance and freedom.

Secondly, if Indonesian in the province can ensure participation of religious leaders and promote a sense of camaraderie between Muslim and Christian priests, it could serve as a positive social model in Nigeria which the Muslim-Christian families and communities can follow. If inter-religious priests spread the word of peace and religious harmony rather than violent conflicts messages, Muslim-Christian families and communities may be dissuaded against religious fights.

If adherents/followers of the both religions comply with public precepts of peace, harmony, respect for dignity of human life as preached in Islam and Christianity, the goal of the critical strategic communication campaign would have been met and Nigeria will attain its destined status of destination for peaceful co-existence. The key messages should be based on the scenarios and situations in Nigeria as identified in four themes for the critical strategic communication campaign. The themes should be incorporated in the mass media intervention programme and should be the guiding objectives in the interpersonal communication outreach efforts.

The message should be framed in symbolic textual content and interpreted for present and future generations of Islam and Christianity for peaceful and harmonious future. The signs, logo and slogan should be designed following this logic: "being Nigerians is a nobility for good people and great nation" and important than the geopolitical or ethnicity we belong to or being in the different religions, but yet one nation. All religions believe in humanity, none believe in violence.
Communication of diverse, critical and proactive strategies leads to successful behaviour and [attitudinal] changes [2]. The planned strategic communication campaign components should be several communication campaigns that must be reflected in multimedia channels to create the desired changes. Multimedia channels are effective in transmitting information or messages, interpersonal communication is more effective in persuading people to adopt new behaviours [7]. Personal level behavioural changes results are more dependent on interpersonal exchanges and relationships [2]. Hence the authors of this article recommend a combination of mass, personal and interpersonal communication with particular attention to local folk media.

Interpersonal communication with personal and folk media can in no small measure help Nigeria understand and determine historical violence between Muslims and Christians with the lessons learned from Indonesia. Therefore, the authors of this article suggest an approach to promote peace among the two groups by utilizing the mixed religious families, unit-by-unit, religious leaders with the students of the other religions via interpersonal outreach elements.

The neutral population's involvement in the religious group reduced to acceptable minimum retaliatory tendencies. Nigerians who are neutral must approach this subject delicately, being that there are very strong opinions from either group. The neutral populations can aid in the mission to establish peace by acting as a go-between for each religious group via interactive "forum" theatre and historic folk media. Theater arts for development and puppetry drama is an effective means of "facilitating development-oriented messages" and "promoting planned change" due to their flexible nature [8].

Sketches of the shows should be performed by students in schools, utilizing familiar folk methods of children in neutral public areas to presents the problems in reflective encouragement of suggestions for potential solutions from the audience. The authors of this article hope that the sketches will build confidence through the message of religious peace into the framework of the every-day domestic religious cultures of Muslims and Christians in Nigeria.

The interactive aspect of this critical strategic communication campaign will help the audience connect with the issues and give them a sense of investment in the solution process which is their solemn desire. Religious leaders and inter-religious family unit in Nigeria should take an active role in promoting unity through outreach programmes. The two religious groups should promote the planned campaign programmes suitable to their co-faith or multi-faith members and friends as well as spread the message of peaceful interaction of Muslims and Christians in Nigeria as experienced in Indonesian.

Students should cultivate the spirit of peace ambassadors by using talk, text and discussion meetings to unite their community members about the benefits of peace with negative highlights of what the future generations risk through prolonged religious conflicts. Student ambassadors should be set up as a forum or platform to spread the message in pairs (one member being Christian and one Muslim) as a sign of compatibility and to avoid resistance by either of the religious groups such as the Boko Haram Sect insurgence.

According to Mr. Suleiman [9] in Tell Magazine cover story, 'recent assault by the Boko Haram Sect reopens fears capable of outwitting the national security in Nigeria (p. 14). The 'Boko Haram Sect' is a Muslim militant social movement which claims to be fighting for the course of enthroning political Islam ideology in Nigeria. The head quarter of the movement is in the out sketch of Bornu State, in Northern Nigeria (pp. 
44-51). This sect claims that it does not recognize the Constitution of Nigeria under the present administration.

Contrary to Mr. Suleiman scenarios, Umukoro [10] 'special report' on the Niger Delta indicates that the situation 'Boko Haram Sect' is fighting for is different from that of the Niger Delta. What the Niger Delta Freedom Fighters are fighting for is over fifty year spillages of crude oil, crude oil pollution, and gas flaring with consequential government neglects.

\section{Findings and recommendations}

The Nigeria Government has not adequately addressed the issue of Boko Haram Sect and what the Niger Delta Region Freedom Fighters are fighting for. Nigeria Government has not utilized the social communication networks established by international organizations and local nongovernmental organizations (NGOs) that have been involved in conflict resolution in Indonesia. Security forces in Nigeria are not applying proactive, robust sand sophisticated control to prevent religious conflict.

This is empirical evidence showing the justification of what the Niger Delta Region Freedom fighters are for. The Niger Delta Region freedom fighters are fighting for emancipation from developmental discrimination. The Nigeria government should build on the networks established by UNEP Environment Assessment Report of Ogoniland to implement the UNEP Report on Ogoniland by declaring the Niger Delta Region a "Special Bioregional Development Administrative Area" in the Nigerian polity.

Nigerian government should review what the Niger Delta Freedom Fighters are fighting for (access to control manage environmental resources for bioregional sustainable development) and issue of Boko Haram Sect with INGOs as partners.

Nigeria Government should implement conflict resolution and promotion of peace in the Northern and in the volatile Niger Delta area. The primarily target of this critical strategic communication campaign should be Muslims and Christians, Islamic institutions in formal and non-formal schools in all the geopolitical zones of Nigeria.

Organized citizen journalism, trained social media practitioners, and mass multimedia channels should be used in raising awareness for this critical strategic communication campaign. Organized mass media should be used to stimulate social networks with peer group conversations to foster proactive religious behavioural changes Islamism and Christendom. The critical strategic communication campaign programmes should be aired on national Radio and Television stations with network capabilities powered by public and private mass media with intergovernmental media organizations.

The intergovernmental media organizations should be commissioned to monitor and coordinated jingles that should inundate the audience on all the airwaves. Newspaper, magazines and social networks should devote reasonable space to educate all patrons until they internalize the precepts of peaceful religious freedom for coexistence as bedrock of national security and development.

Radio public service announcement in conjunction with radio soap operas and home videos should be used fin campaign. The radio spots should be based on the planned critical strategic communication campaign themes with local artist and popular tunes. The radio soap should have a story line involving inter-religious relationshiphighlighting mixed family units, friendships, social ties and romantic relationship between Muslims and Christians.
Radio should be augmented with component of posters and pamphlets with highly cultural visible meaningful print media religious communications. The poster and pamphlets should consist of the specific, general and performance objectives of the critical strategic communication campaign messages outlined and specified from the radio soaps, the TV jingles, and home videos messages.

Radio, TV, posters and pamphlets are the most useful mode of conveying the religious message to the targeted populations. A pamphlet allows people to keep something with them and hopefully think about it. The pamphlet should draw upon the tenets from both religions sacred texts that stand for peace, non violence and peaceful coexistence. For example, when public outcries hit crescendo, illicit worries beat retreat and lay down arms as in the case of the Niger Delta Freedom Fighters. To forestall resurgence from retreat, the message of this critical strategic communication campaign should be deliberately prolonged.

\section{Conclusion}

Students in formal and non-formal education arenas have historically played a critical role in social movements and are the future generations that most benefit from peaceful nation where they grow and develop in all spheres of their lives. It is the hope of the authors of this article that the family units where the students come from should help spread the message of unity in religious diversity and for freedom to their friends and associates through social diffusion.

Radio and Television are the most common ways to spread information aired on neutral stations and networks. Radio and Television programmers should be involve in further realist evaluation communication research (background analysis and pre-testing). Monitoring and evaluation cost (mid-term evaluation and summation to add new ideas). Production cost (radio and Television spots, radio serial drama, and other campaign materials should be considered).

Airing costs, theatre cost (selection and training of actors by theatre professionals, costumes, microphones etc), charges for key facilitators (student peace ambassadors and religious leaders), personnel (salary for two full time campaign consultants) and outreach efforts (preprogramme publicity and continuity) and contingency funds are required to execute this campaign. Further research that can be used to identify and asses how the audience's need should be conducted to find out who are the key players in the Boko Haram Sect in comparison with the Niger Delta Region Freedom Fighters in Nigeria, how much they know and what they need to know.

The activities of 'Boko Harma Sect' and the retreated Niger Delta Region Freedom Fighters in Nigeria requires realistic socio scientific evaluation after the completion of the first year of the critical strategic communication campaign to determine whether the programme objectives were met and to gather inputs from the audience about the programme achievements and outcomes.

\section{References}

1. International Crisis Group (ICG) (2002) Indonesia: The search for peace in Maluku. ICG Asia Reports No 31, UNICEF.

2. Mckee N, Manoncourt E, Saik YC, Carnegie R (2000) Involving People Evolving Behaviour. Southbound \& UNICEF: Penang.

3. Bertrand J (2004) Nationalism and ethnic conflict in Indonesia. New York: Cambridge University Press.

4. Piotrow PT, Lawrence Kincaid D, Jose Rimon II, Ward R (1997) Health Communication: Lessons from family planning and reproductive health. Westport, CT: Praeger. 
Citation: Nwanyanwu NC, Ikoro NJ, Eke SC (2013) Programmatic Communication for Religious Peace in Nigeria: Lessons Learned from Indonesia. J Mass Communicat Journalism 3: 150. doi:10.4172/2165-7912.1000150

Page 5 of 5

5. Singhal A, Rogers EM (2003) Combating AIDS: Communication Strategies in action. New Delhi: Sage Publication.

6. Ehrenfeld R, Lappen A (2009) In Norwitz, J. (2009 Ed.). Pirates, Terrorists, and Warlords: The History, Influence, and Future of Armed Groups around the World. Skyhorse Publishing: New York.

7. Rogers EM (2003) Diffusion of Innovations. New York: Free Press.
8. Melkote SR, Leslie HS (2001) Communication for Development in the Third Wordl: Theory and Practice for Empowerment. 2nd ed., London: Sage Publication.

9. Suleiman T (2011) Living in the shadows of "Boko Haram Sect". Tell Lagos 46: 44-57.

10. Ibid Umukoro A (2011) Niger Delta rage over spills. Tell Lagos 46: 52-59. 